\title{
AP-2 $\alpha$ expression and cell apoptosis of the lung tissue of rats with COPD and ECV304 cells stimulated by cigarette smoke extract
}

\author{
LI JunLi ${ }^{\dagger}$, CHEN Yan ${ }^{\dagger}$, CHEN Ping ${ }^{*}$, CAI Shan, PENG Hong, ZHOU Rui, XIANG XuDong, \\ LONG Hong \& LIU ShaoKun
}

Department of Respiratory Medicine, Xiangya Second Hospital of Central South University, Changsha, Hunan 410011, China

Received August 30, 2010; accepted February 18, 2011; published online April 13, 2011

\begin{abstract}
An increasing body of evidence suggests that apoptosis of structural cells in the lung might be an important upstream event in the pathogenesis of chronic obstructive pulmonary disease (COPD). AP- $2 \alpha$ is one of the important transcription factors involved in the modulation of apoptosis in carcinogenesis and idiopathic-dilated cardiomyopathy. The relationship between AP- $2 \alpha$ and apoptosis in COPD remains to be elucidated. The aim of the present study was to investigate the expression of AP-2 $\alpha$ in the lung tissues of rats with COPD induced by smoking and its possible protective effect on cigarette smoke extract (CSE) induced endothelial cell apoptosis. Sprague-Dawley rats $(n=24)$ were randomly assigned to normal and COPD groups. The COPD group was exposed to smoke from 20 commercial unfiltered cigarettes for $80 \mathrm{~d}$ before morphological assessment of the lung tissue was performed. The expression of AP-2 $\alpha$ in lung tissues was measured by Western blotting. To demonstrate the relationship between apoptosis and AP- $2 \alpha$, in vitro cell experiments were carried out. Cells were treated with different concentrations of CSE before proliferation was measured by MTT. Apoptosis was then determined by Hoechst staining and the expression of cleaved caspase- 3 and AP- $2 \alpha$ by Western blotting over time following treatment with 5\% CSE. Cells were then infected with an AP-2 $\alpha$ adenovirus vector and the expression of cleaved caspase- 3 and AP- $2 \alpha$ was compared to the control groups by Western blotting. The COPD group showed larger air spaces and significant decrease of $\mathrm{FEV}_{0.3} / \mathrm{FVC}$ compared with the rats in the control group $(P<0.05)$. The expression of AP- $2 \alpha$ was significantly higher in the lung tissue of rats with COPD compared with those of controls $(P<0.05)$. In the ECV304 cells, CSE induced apoptosis $(P<0.01)$ and caspase-3 activation in a time-dependent manner and reduced the cell proliferation rate in a dose-dependent manner $(P<0.005)$. Moreover, 5\% CSE treatment increased endogenous AP-2 $\alpha$ protein expression. AP- $2 \alpha$ overexpression inhibited 5\% CSE-induced cell apoptosis and activated caspase-3 expression $(P<0.05)$ AP- $2 \alpha$ protects ECV304 cells against CSE-induced apoptosis and may play an important role in smoking induced-apoptosis in COPD.
\end{abstract}

AP-2 $\alpha$, apoptosis, cigarette smoke extract, COPD, vascular endothelial cell

Citation: $\quad$ Li J L, Chen Y, Chen P, et al. AP-2 $\alpha$ expression and cell apoptosis of the lung tissue of rats with COPD and ECV304 cells stimulated by cigarette smoke extract. Chinese Sci Bull, 2011, 56: 1562-1568, doi: 10.1007/s11434-011-4437-8

Chronic obstructive pulmonary disease (COPD) is one of the major public health problems because of its high morbidity and mortality, but its pathogenesis remains enigmatic. Cigarette smoking is one of the major etiological factors of COPD, with the mechanisms including chronic inflammation [1], elastase/antielastase imbalance [2] and oxidant/ antioxidant imbalances [3]. Recently, more and more studies

†These authors contributed equally to this work.

*Corresponding author (email: pingchen0731@ sina.com) have shown increased apoptosis in the alveolar walls in COPD patients [4] and COPD animal models [5] induced by cigarette smoke exposure. Some studies related apoptosis in alveolar walls to emphysema in animal models. The pro-apoptosis mechanisms of cigarette smoke exposure were related to activated caspase [6], decreases in VEGF and VEGFR-2 [7], increased oxidative stress [8], inflammation and impaired repair responses [9].

Activator protein-2 (AP-2) is a family of cell type-specific and developmentally regulated transcription factors. To date, 
five members of the AP- 2 family including AP- $2 \alpha$, AP- $2 \beta$, $\mathrm{AP}-2 \gamma, \mathrm{AP}-2 \delta$ and $\mathrm{AP}-2 \varepsilon$ have been identified. AP- $2 \alpha$ has been implicated in vertebrate development, embryogenesis [10], carcinogenesis [11] and idiopathic-dilated cardiomyopathy [12]. As a transcription factor, AP- $2 \alpha$ was suggested to associate with apoptosis by modulating the expressions of many genes such as VEGF [13], $\mathrm{P}^{53}$ [14], p21WAF/CIP [15], Bcl-2 [16] and manganese superoxide dismutase (MnSOD) [17].

Based on the important status of apoptosis in COPD and that AP- $2 \alpha$ is involved in apoptosis in many diseases, in this study we investigated the expression of AP-2 $\alpha$ in the lung tissue of smoking-induced COPD rats as well as the effect of AP-2 $\alpha$ over-expression in the CSE-induced apopotosis of ECV304 cells.

\section{Materials and methods}

\subsection{Animals}

Twenty-four male Sprague-Dawley rats, each weighing 186-240 g, were purchased from the Animal Center of the Second Xiangya Hospital, Changsha, China. The rats were randomly assigned to two groups of 12: normal control and COPD groups. The COPD group was exposed to smoke from 20 commercial unfiltered cigarettes (Furong, Changde Cigarette Factory, Changde, Hunan, China) for $1 \mathrm{~h}$ each day, $6 \mathrm{~d}$ a week, for a total of $80 \mathrm{~d}$. The smoke exposure box was $69 \mathrm{~cm} \times 47 \mathrm{~cm} \times 38 \mathrm{~cm}$. The control group were treated the same as the COPD group except with the absence of smoke exposure. Experiments were approved by the animal ethics committee and were performed following strict government and international guidelines.

\subsection{Morphological assessment}

After fixation, 5- $\mu \mathrm{m}$ lung sections were stained with hematoxylin and eosin (HE) stain. As emphysema is a structural disorder characterized by destruction of the alveolar walls and enlargement of the alveolar spaces, enlargement of alveolar spaces was assessed by quantifying the mean linear intercept (MLI) and destruction of alveolar walls by measuring the destructive index (DI) [18]. MLI, a measure of inter-alveolar wall distance, was determined by light microscopy at a magnification of $100 \times$. Fields that included large airways or vessels were excluded from the analysis. MLI was defined as the total length of the cross-line divided by the numbers of alveolar walls intersecting the test lines, as described by Xu et al. [19]. DI was calculated as a measure of parenchymal destruction using a microscopic pointcount technique [20]. The analysis was performed in duplicate by randomly counting more than 3000 alveoli from 50 HE sections from each rat at a magnification of $200 \times$. For each photomicrograph, a single observer who was blind to the related data performed the measurements.

\subsection{Pulmonary function}

Half of the rats from the two groups were randomly selected for lung function measurements, according to the method described by Chen et al [21]. After induction of anaesthesia by intraperitoneal administration of chloral hydrate (3 $\mathrm{mL} / \mathrm{kg}$ ), a Y-type endotracheal cannula was connected to a flow transducer (HX200, Beijing Xinghangxingye Corporation, Beijing, China) for measurement of FEV0.3/FVC (Forced expiratory volume in 0.3 s/Forced vital capacity) and PEF (Peak expiratory flow).

\subsection{Cell culture}

ECV304 cells obtained from the Xiangya Type Culture Collection (Changsha, China), were cultured in RPMI medium 1640 supplemented with $10 \%$ heat-inactivated newborn bovine serum and antibiotic-antimycotic mix in a humidified incubator with $5 \% \mathrm{CO}_{2}$ and $95 \%$ air. At $70 \%-80 \%$ confluence, ECV304 cells were treated with CSE and/or adenovirus infection.

\subsection{Preparation of cigarette smoke extract (CSE)}

CSE was generated by bubbling smoke from 1 standard reference cigarette into $20 \mathrm{~mL}$ RPMI medium 1640 (Life Technologies, California, USA) through a $50-\mathrm{mL}$ fritted impinger at a flow rate of $350 \mathrm{~mL} / \mathrm{min}$. The resulting extract was passed through a $0.22-\mu \mathrm{m}$ filter and was considered $100 \%$ CSE. The CSE was adjusted to $\mathrm{pH} 7.4$ by the addition of $\mathrm{NaOH}$ before being diluted to $2.5 \%-20 \%$ concentration with RPMI medium 1640 and used within $1 \mathrm{~h}$.

\subsection{Adenovirus reagents and infections}

The Ad-AP-2 $\alpha$ adenovirus vector and its control Ad-BgII were generously provided by Dr F. Domann of Iowa University (USA). Adenoviral infections were carried out as described [22]. Briefly, $5 \times 10^{5}$ cells were plated in a $60-\mathrm{mm}$ culture dish. After $24 \mathrm{~h}$ of culture, when reaching $80 \%$ confluence, the cells were washed three times using PBS. Adenoviral titers were determined and transient infections were carried out using an MOI of 100. After another 24-h culture in free-serum medium, the cells were collected or 5\% CSE was added for culturing another $24 \mathrm{~h}$, then the cells were harvested for Hoechst staining and Western blot analysis.

\subsection{Hoechst 33258 nuclear staining assay}

Nuclear staining with Hoechst 33258 (Sigma Chemical Co, USA) was performed as described elsewhere [23]. Briefly, the floating and trypsinized-adherent CSE treated and nontreated cells were collected at appropriate time points, washed with PBS and then fixed with $4 \%$ paraformaldehyde in PBS for $30 \mathrm{~min}$ at $4^{\circ} \mathrm{C}$. After washing, the cells were 
smeared onto microscope slides followed by incubation in Hoechst 33258 at a final concentration of $30 \mu \mathrm{g} / \mathrm{mL}$ at room temperature for $5 \mathrm{~min}$. Nuclear morphology was then examined under a fluorescent microscope (Imaging Source Europe $\mathrm{GmbH}$, Bremen, Germany). The analysis was performed in duplicate by randomly counting more than 500 nuclei from each concentration at a magnification of $100 \times$. For each photomicrograph, a single observer who was blind to the related data performed the measurements.

\subsection{MTT assay}

The MTT assay was carried out as described previously [24]. Cells were plated in a 96-well plate at $1.3 \times 10^{4} /$ well. After $24 \mathrm{~h}$ of plating, the cells were treated with $0,2.5 \%$, $5 \%, 10 \%, 15 \%$ or $20 \%$ CSE for $24 \mathrm{~h}$ before MTT $(20 \mu \mathrm{L}$ of $5 \mathrm{mg} / \mathrm{mL}$ ) was added. The medium was removed from the wells $4 \mathrm{~h}$ after MTT addition, and $100 \mu \mathrm{L}$ of dimethyl sulfoxide was added to dissolve the formazan crystals before the absorbance was measured at $570 \mathrm{~nm}$ in an enzymelinked immunosorbent assay reader.

\subsection{Western blotting analysis}

Nuclear and cytoplasmic extracts were prepared according to the method of Schreiber et al. [25]. Briefly, lung homogenate or the cell pellet was resuspended in $400 \mu \mathrm{L}$ of cold buffer A (10 mmol L ${ }^{-1}$ HEPES pH 7.9, $10 \mathrm{mmol} \mathrm{L}^{-1}$ $\mathrm{KCl}, 0.1 \mathrm{mmol} \mathrm{L}{ }^{-1}$ EDTA, $0.1 \mathrm{mmol} \mathrm{L}^{-1}$ EGTA, $1 \mathrm{mmol}$ $\mathrm{L}^{-1}$ DTT, $\left.0.5 \mathrm{mmol} \mathrm{L}{ }^{-1} \mathrm{PMSF}\right)$. The cells were allowed to swell on ice for $15 \mathrm{~min}$, after which $25 \mu \mathrm{L}$ of a $10 \%$ solution of NP-40 was added and the tube was vigorously vortexed for $10 \mathrm{~s}$. The homogenate was centrifuged for $30 \mathrm{~s}$ in a microcentrifuge and the supernatant containing the cytoplasmic extract was removed. The nuclear pellet was resuspended in $50 \mu \mathrm{L}$ of ice-cold buffer B $\left(20 \mathrm{mmol} \mathrm{L}^{-1}\right.$ HEPES pH 7.9, $0.4 \mathrm{~mol} \mathrm{~L}^{-1} \mathrm{NaCl}, 1 \mathrm{mmol} \mathrm{L}{ }^{-1}$ EDTA, 1 mmol L ${ }^{-1}$ EGTA, $1 \mathrm{mmol} \mathrm{L}^{-1}$ DTT, $1 \mathrm{mmol} \mathrm{L}^{-1}$ PMSF) and the tube was vigorously rocked at $4^{\circ} \mathrm{C}$ for $15 \mathrm{~min}$ on a shaking platform. The nuclear extract was centrifuged for $5 \mathrm{~min}$ in a microcentrifuge at $4^{\circ} \mathrm{C}$ and the supernatant was frozen in aliquots at $-80^{\circ} \mathrm{C}$. The protein contents of the different fractions were determined by the Bradford assay method.

Proteins from the subcellular fractions were mixed with $2 \times$ SDS sample buffer (100 mmol L ${ }^{-1}$ Tris- $\mathrm{HCl}$ (pH6.8), 4\% SDS (w/v), 20\% glycerol, $200 \mathrm{mmol} \mathrm{L}{ }^{-1}$ DTT, 0.1\% bromophenol blue (w/v)) and boiled in a water bath for $5 \mathrm{~min}$, before separation on $10 \%$ polyacrylamide gels and transfer to a polyvinylidene difluoride membrane (Millipore, Bedford, MA, USA). The membrane was then blocked in blocking buffer at room temperature for $6 \mathrm{~h}$, incubated for $2 \mathrm{~h}$ at $25^{\circ} \mathrm{C}$ with primary antibody (mouse anti-AP- $2 \alpha$ monoclonal antibody (Santa Cruz, US; 1 : 1000); mouse anti-caspase-3 monoclonal antibody (Beyotime Institute of Biotechnology, China;
$1: 250)$; mouse anti-proliferating cellular nuclear antigen (PCNA) monoclonal antibody (Upstate, US; 1:1000)), followed by horseradish peroxidase-conjugated secondary antibody IgG (Jackson Biotech, US; $1: 1000$ ), for $1 \mathrm{~h}$ at $25^{\circ} \mathrm{C}$. Proteins were visualized using enhanced chemiluminiscence reagent (Amersham Pharmacia Biotech, UK) and X-ray film.

\subsection{Statistical analysis}

Data were presented as means \pm SEM. Significance of differences between groups was determined using ANOVA with two-tailed Student's t test or LSD test. Multiple rate comparisons were examined by the $\chi^{2}$ test. $P<0.05$ was considered significant.

\section{Results}

\subsection{Establishment of a rat model of COPD and the expression of AP-2 $\alpha$ in lung tissue of COPD rats}

(i) Histological studies. HE staining of lung tissue sections from the COPD group showed histologically advanced emphysema. In contrast, histological markers of emphysema were absent in lung tissue sections obtained from the normal group (Figure 1). The MLI and DI in the COPD group (77 $\pm 29 \mathrm{~mm}$ and $59 \% \pm 7 \%$, respectively) were significantly higher than those in the normal group $(44 \pm 7 \mathrm{~mm}$ and $18 \% \pm 5 \%)$. There was increased inflammatory cell infiltration in COPD rat lungs compared with normal rat lungs, as assessed by light microscopic examination of HE-stained slides.

(ii) Lung function. $\mathrm{FEV}_{0.3} / \mathrm{FVC}$ and $\mathrm{PEF}$ were lower in the COPD group $(65.1 \% \pm 8.4 \%$ and $18.8 \pm 1.6 \mathrm{~mL} / \mathrm{s}$, respectively) compared with the normal group $(85.6 \% \pm 5.9 \%$ and $47.2 \pm 7.3 \mathrm{~mL} / \mathrm{s})(P<0.05)$.

(iii) Expression of AP-2 $\alpha$ in lung tissue of COPD rats. AP- $2 \alpha$ protein expression in lung nuclear extracts from rats in the two experimental groups was assessed by Western blotting. The expression of AP- $2 \alpha$ was increased in the COPD group compared with the normal group (Figure 2).

\subsection{Cell proliferation, apoptosis and activation of caspase-3 in ECV304 cells treated with CSE}

To assay the cytotoxic potential of CSE, the influence of different concentrations of CSE on the viability of ECV304 cells was measured by MTT assay. Compared with the control group, proliferation was significantly increased in the $2.5 \%$ CSE-treated group, while it decreased in a concentration-dependent manner in the remaining CSE-treated groups $(P<0.01)$ (Figure 3).

To examine the cell apoptosis in response to CSE treatment, both control and 5\% CSE-treated cells were stained with the fluorescent Hoechst 33528 dye and visualized 


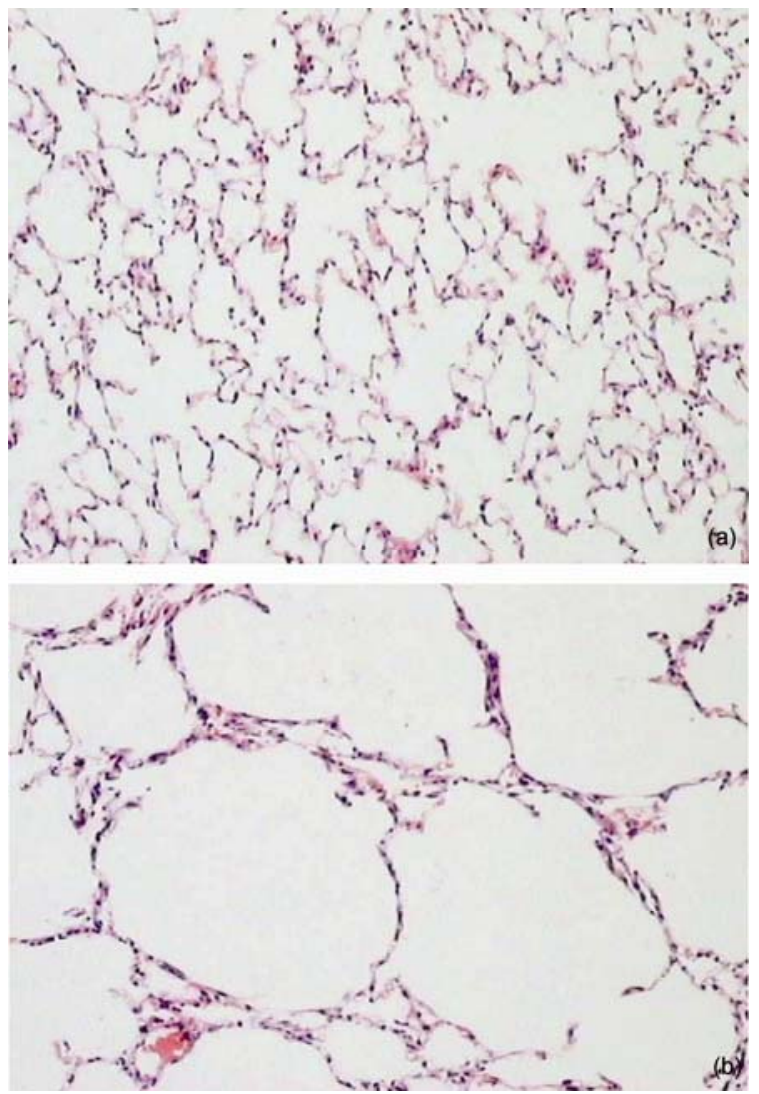

Figure 1 HE staining of lung tissue sections from rats in the normal group (a) and the COPD group (b) (100x).

under a fluorescence microscope. Figure 4 shows the Hoechst staining results for 5\% CSE treated-ECV304 cells over $48 \mathrm{~h}$. ECV304 cells at $0 \mathrm{~h}$ remained uniformly stained. At $12 \mathrm{~h}$, the cells began to display apoptotic morphology, such as enucleation and apoptotic bodies. At $24 \mathrm{~h}$, nuclear condensation and fragmentation were more apparent, with the chromatin condensed into lumps, exhibiting punctated morphology typical of apoptotic cells. At 36 and $48 \mathrm{~h}$, apoptotic events culminated in the formation of apoptotic bodies, seen as smaller intensly stained spots. Shrinkage of cells, DNA condensation and even some cell destruction were observed.

The expression levels of activated caspase- 3 were increased in ECV304 cells treated with 5\% CSE in a time-dependent manner (Figure 5(a)). Compared with the untreated cells, caspase-3 levels increased to $135 \%$ at $12 \mathrm{~h}, 244 \%$ at $18 \mathrm{~h}, 289 \%$ at $24 \mathrm{~h}$ and $323 \%$ at $36 \mathrm{~h}$, respectively (Figure 5(b)).

\subsection{The expression of AP-2 $\alpha$ was induced by 5\% CSE in ECV304}

The expression of AP-2 $\alpha$ protein in ECV304 cells treated with

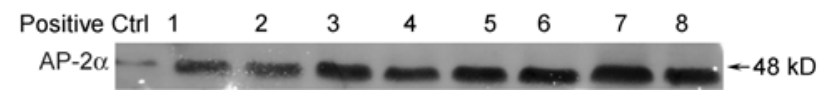

Figure 2 Western blot analysis of AP- $2 \alpha$ protein expression in lung nuclear extracts. Lanes 1 and 2, normal group; lanes 3-8, COPD groups. HeLa cell nuclear extract was used as a positive control.

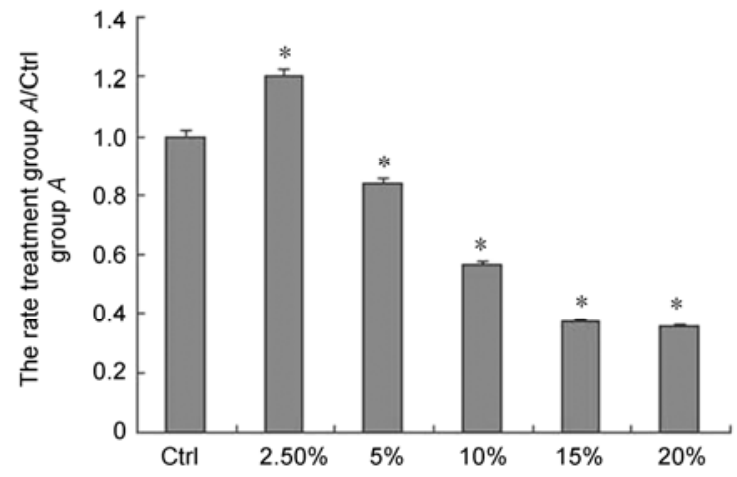

Figure 3 ECV304 cells were treated with a concentration of $0,2.5 \%, 5 \%$, $10 \%, 15 \%$ and $20 \%$ of CSE for $24 \mathrm{~h}$, and the cell viability was quantified using the MTT assay. The absorbance for 0\% CSE group (control group) was considered as $100 \%$. The abscissa indicates different groups; The $Y$-axis indicates the ratio of treatment group $A / \mathrm{Ctrl}$ group $A .{ }^{*}, P<0.05$ compared with the control group.
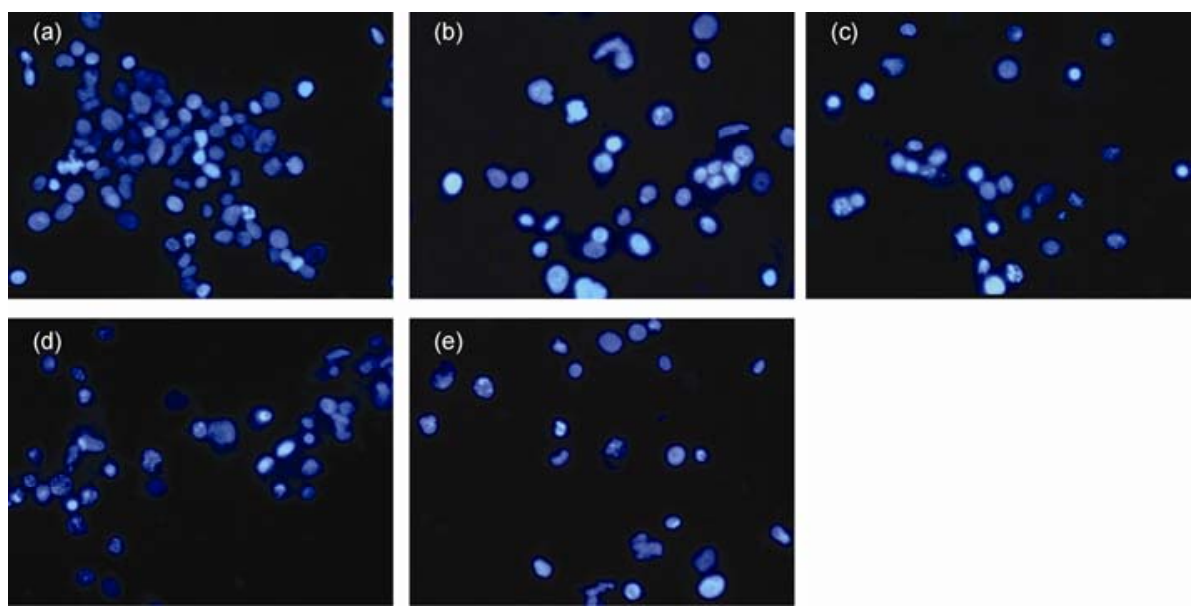

Figure 4 Nuclear staining of ECV304 cells with Hoechst 33258. Cells were treated with 5\% CSE. (a) Untreated (control) ECV304 cells remained uniformly stained with round and unpunctuated nuclei; (b) 5\% CSE at $12 \mathrm{~h}$; (c) $5 \%$ CSE at $24 \mathrm{~h}$; (d) $5 \%$ CSE at $36 \mathrm{~h}$; (e) $5 \%$ CSE at $48 \mathrm{~h}$. 5\% CSE-treated ECV304 cells showed apoptotic morphology: cell shrinkage, DNA condensation and nuclear fragmentation. 

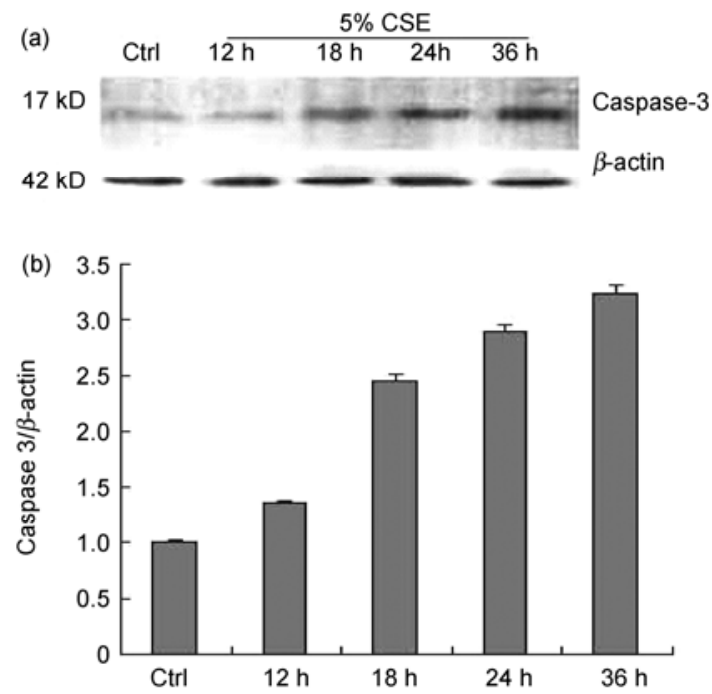

Figure 5 The expression of activated caspase- 3 was analyzed by Western blotting in ECV304 cells treated with 5\% CSE for 0, 12, 18, 24 and $36 \mathrm{~h}$, respectively. The nuclear and cytoplasmic fractions were isolated and the level of activated caspase- 3 was assayed by Western blotting (a). $\beta$-actin was used as an internal control. (b) Compared with the control, the expressions of activated caspase-3 at 18, 24 and $36 \mathrm{~h}$ were significant $(P<0.001, n=3)$.

5\% CSE was detected by Western blotting. The expression level of AP-2 $\alpha$ increased in a time-dependent manner (Figure $6(\mathrm{a})$ ), with levels increasing to $106 \%$ at $6 \mathrm{~h}, 125 \%$ at 12 $\mathrm{h}, 139 \%$ at $24 \mathrm{~h}$ and $161 \%$ at $48 \mathrm{~h}$, respectively, compared to untreated controls (Figure 6(b)).

\subsection{Overexpression of AP- $2 \alpha$ by adenoviral infection inhibited both apoptosis and caspase- 3 activation induced by CSE in ECV304}

(i) Expression of AP- $2 \alpha$ in Ad-AP-2 $\alpha$-infected cells. To
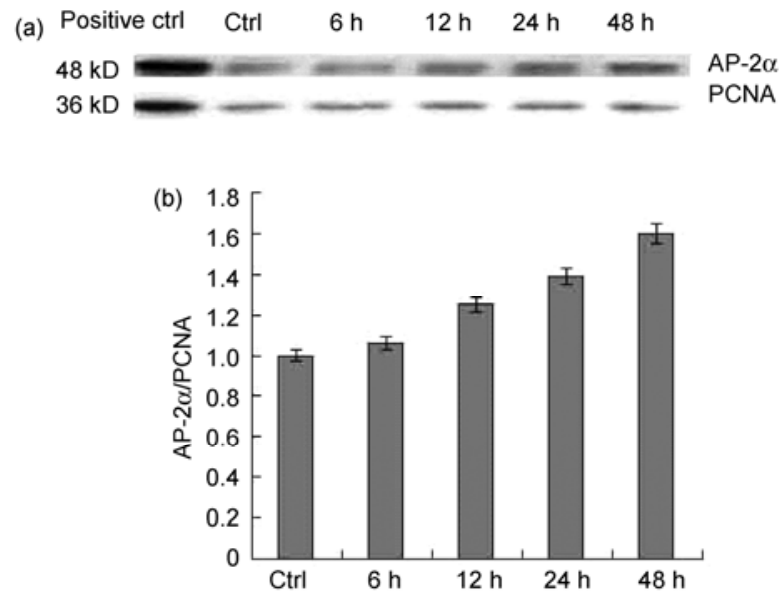

Figure 6 The expression of AP-2 $\alpha$ induced by 5\% CSE. The cells were stimulated with 5\% CSE for $0,6,12,24$ and $48 \mathrm{~h}$. Nucleoproteins were isolated and the levels of AP- $2 \alpha$ were assayed by Western blotting. HeLa cells were used as the positive control. PCNA was used as an internal control. (a) There was a time-dependent increase in the expression level of AP-2 $\alpha$; (b) compared with Ctrl (0\% CSE), the expression levels of AP- $2 \alpha$ at 12,24 and $48 \mathrm{~h}$ were increased significantly $(P<0.05$ for all, $n=3)$. detect the induced expression of AP- $2 \alpha$ protein in Ad-AP$2 \alpha$-infected ECV304 cells, AP- $2 \alpha$ protein levels were monitored and compared to the levels in cells infected with the control virus Ad-BgII. At $24 \mathrm{~h}$ after infection, nuclear extracts were collected and the expression of AP- $2 \alpha$ protein was assessed. Upon Ad-AP-2 $\alpha$ infection, ECV304 cells showed twice the amount of AP- $2 \alpha$ protein in comparison with Ad-BgII transfection (Figure 7(a)).

(ii) AP-2 $\alpha$ overexpression inhibited the apoptosis induced by CSE in ECV304. To study the effect of AP- $2 \alpha$ on apoptosis induced by CSE, we stimulated ECV304 cells with 5\% CSE $24 \mathrm{~h}$ after infection with Ad-BgII and Ad-AP-2 $\alpha$, before assessing the morphological changes 24 $\mathrm{h}$ later. ECV304 cells infected with Ad-BgII displayed apoptotic morphology, such as enucleation and apoptotic bodies, whereas ECV304 infected with Ad-AP-2 $\alpha$ showed fewer apoptotic cells than with Ad-Bg-II $(P<0.005, n=3)$ (Figure 7(b)).

(iii) AP-2 $\alpha$ overexpression inhibited caspase- 3 activation induced by CSE in ECV304. To study the effect of AP-2 $\alpha$ on the activation of caspase- 3 induced by CSE, ECV304 cells were treated as described in section (ii) before the protein level of activated caspase-3 (17 kD) was measured by Western blot (Figure 7(c)). Compared with the Ad-BgII 24 $\mathrm{h}$ group, the expression of activated caspase- 3 is significantly decreased in the Ad-AP-2 $\alpha$ group $(P<0.001)$.

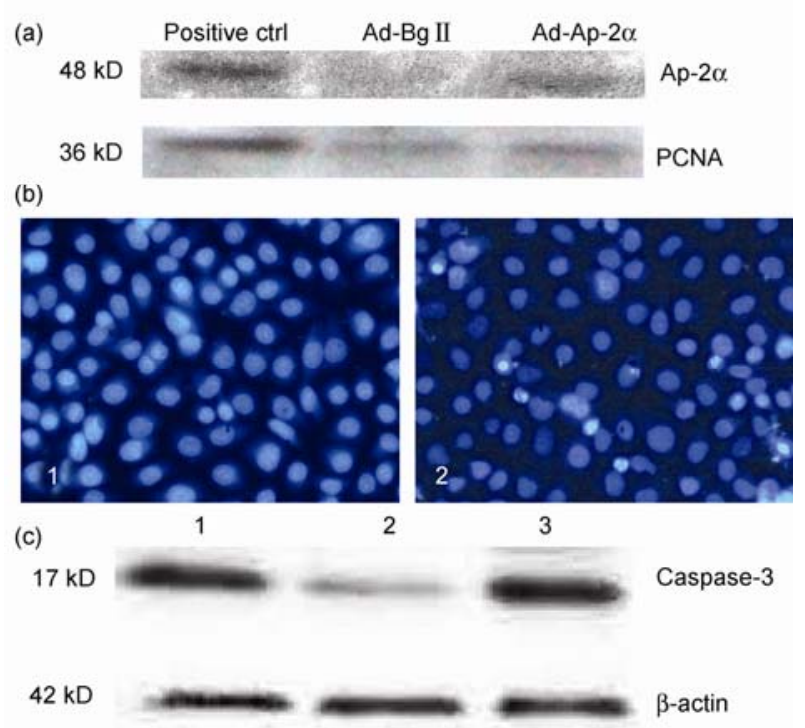

Figure 7 The effect of AP-2 $\alpha$ over-expression on CSE-induced apoptosis. (a) The induced expression of AP- $2 \alpha$ protein in Ad-AP- $2 \alpha$-infected ECV304 cells. (b) Nuclear staining of ECV304 cells with Hoecsht 33258. ECV304 cells were infected with AP-2 $\alpha$ (1) or Ad-BgII (2) for $24 \mathrm{~h}$, and then stimulated with $5 \% \mathrm{CSE}$ for $24 \mathrm{~h}$. (c) Effect of AP-2 $\alpha$ overexpression on the activation of caspase-3 (17 kD) induced by CSE in ECV304 cells. $\beta$-actin was used as an internal control. Lane 1, ECV304 cells were infected with Ad-BgII for $24 \mathrm{~h}$, and then treated with 5\% CSE for $24 \mathrm{~h}$; lane 2 , ECV304 cells were infected with Ad-AP- $2 \alpha$ for $24 \mathrm{~h}$, then treated with $5 \%$ CSE for $24 \mathrm{~h}$; lane 3, ECV304 cells were cultured with a serum-free medium for $24 \mathrm{~h}$, and then treated with $5 \%$ CSE for $24 \mathrm{~h}$. 


\section{Discussion}

COPD is characterized by chronic inflammation of the airways and progressive destruction of lung parenchyma. Emphysema is a major component of COPD and cigarette smoking is the single most important factor in the development of emphysema. The present study showed that exposure of rats to cigarette smoke decreased their FEV0.3/FVC and PEF, consistent with the clinical observations in COPD patients. There were obvious emphysematous changes in the COPD group, including enlargement of alveolar spaces and destruction of alveolar walls, which were quantified by measuring MLI and DI, respectively. MLI and DI were increased in the lungs of rats in the COPD group compared with those in the normal group. These results suggest that a rat model of COPD was successfully established.

Recently, an increasing body of evidence suggests that apoptosis of structural cells in the lung might be an important upstream event in the pathogenesis of COPD. There is an increase in the number of apoptotic cells in the lungs of COPD patients. Because this is not counterbalanced by an increase in proliferation of these structural cells, the net result is destruction of lung tissue and the development of emphysema.

Increasing evidence demonstrates that AP- $2 \alpha$ is involved in apoptosis. In some tissues the expression of AP- $2 \alpha$ is decreased or lost resulting in apoptosis increase. In addition, AP-2 $\alpha$ functions as an anti-apoptotic factor in epithelial ovarian cancer [26], colorectal adenomas and adenocarcinomas [27], human gliomas [28], prostate cancer cells [29] and melanoma [30]. In contrast, AP- $2 \alpha$ expression is increased and functions as a pro-apoptotic factor in human failing myocardium with idiopathic-dilated cardiomyopathy and in human breast cancer [31]. We show that AP-2 $\alpha$ protein was expressed and increased in the lung of a rat model of COPD induced by cigarette smoke exposure, and was associated with increased cell apoptosis. It is unclear whether there was a direct relationship between the increase in AP- $2 \alpha$ and the increase in cell apoptosis.

Lung alveolar walls cells includes epithelial cells, endothelial cells and interstitial cells. Taraseviciene-Stewart et al. [32] developed a model of autoimmune emphysema in adult rats by intraperitoneal injection of human umbilical vein endothelial cells (HUVECs). In this model, anti-VEGF receptor antibodies were generated and apoptosis, especially of endothelial cells, occured in the lung. This suggests the importance of endothelial cell apoptosis in COPD.

The ECV304 cell line, although identified as a bladder carcinoma cell line, displays some endothelial characteristics including tubule formation (differentiation) following appropriate stimulation $[33,34]$. We used ECV304 cells to study the role and mechanisms of AP- $2 \alpha$ in vascular endothelial cell apoptosis induced by cigarette smoke exposure. Compared with the control group, proliferation was signifi- cantly increased in cells treated with $2.5 \%$ CSE, while it decreased in a dose-dependent manner at concentrations higher than $2.5 \%$. Apoptosis was also increased in a time-dependant manner in cells exposed to 5\% CSE. At higher concentrations of CSE (15\%-20\%) necrosis was evident. The increased proliferation at low concentration or short-period exposure to CSE may be because the low levels of damaging factors present were unable to induce apoptosis but could induce oncogenic mutation. This may be one reason why lung cancer is prone to occur in smokers. Higher CSE concentration or longer periods of stimulation with CSE leads to apoptosis or even necrosis, consistent with the results from other researchers [35,36]. Besides treatment factors, cell type [37] is also one factor that can affect cell apoptosis or necrosis when stimulated.

The expressions of cleaved caspase- 3 and AP- $2 \alpha$ in ECV304 cells were increased in a time-dependent manner following 5\% CSE treatment. The activation of caspase-3 is considered an important index of cell apoptosis. To probe the relationship between the expression of AP- $2 \alpha$ and the activation of caspase-3, we successfully infected ECV304 cells with Ad-AP-2 $\alpha$. As the results show, over-expression of AP- $2 \alpha$ inhibited ECV304 cell apoptosis and caspase-3 activation induced by CSE. This suggests that AP- $2 \alpha$ might protect ECV304 cells from CSE. There is no report showing that AP- $2 \alpha$ directly modulates the expression, activation or cleavage of caspase-3. Possible mechanisms for AP- $2 \alpha$ inhibition of apoptosis include inhibiting the expression of Mn-SOD [38], down-regulating the expression and inhibitting the activation of MMP-9 [39], negative regulation of c-MYC activity [40] activating some oncogene such as HER-2/neu [31] and interfering with the cytokine network [41].

This is the first report to demonstrate that the expression of AP-2 $\alpha$ is increased in lung tissue of COPD rats and ECV304 cells stimulated by cigarette smoke exposure. Adenoviral-mediated over-expression of AP- $2 \alpha$ protects against ECV304 cell apoptosis and caspase-3 activation induced by CSE. These results suggest that AP- $2 \alpha$ might protect endothelial cells against CSE and rat lung tissue against cigarette smoke exposure. Knocking out the AP- $2 \alpha$ gene in rats would confirm these observations.

This work was supported in part by the National Natural Science Foundation of China (30770931, 81070039).

1 Betsuyaku T, Nishimura M, Takeyabu K, et al. Neutrophil granule proteinsin bronchoalveolar lavage fluid from subjects with subclinical emphysema. Am J Respir Crit Care Med, 1999, 159: 1985-1991

2 Cataldo D, Munaut C, Noël A, et al. MMP-2- and MMP-9-linked gelatinolytic activity in the sputum from patients with asthma and chronic obstructive pulmonary disease. Int Arch Allergy Immunol, 2000, 123: 259-267

3 Tuder R M, Zhen L, Cho C Y, et al. Oxidative stress and apoptosis interact and cause emphysema due to vascular endothelial growth factor receptor blockade. Am J Respir Cell Mol Biol, 2003, 29: 
$88-97$

4 Kasahara Y, Tuder R M, Cool C D, et al. Endothelial cell death and decreased expression of vascular endothelial growth factor and vascular endothelial growth factor receptor-2 in emphysema. Am J Respir Crit Care Med, 2001, 163: 737-744

5 Aoshiba K, Yokohori N, Nagai A. Alveolar wall apoptosis causes lung destruction and emphysematous changes. Am J Respir Cell Mol Biol, 2003, 28: 555-562

6 Chen Y, Hanaoka M, Chen P, et al. Protective effect of beraprost sodium, a stable prostacyclin analog, in the development of cigarette smoke extract-induced emphysema. Am J Physiol Lung Cell Mol Physiol, 2009, 296: L648-L656

7 Tang K, Rossiter H B, Wagner P D, et al. Lung-targeted VEGF inactivation leads to an emphysema phenotype in mice. J Appl Physiol, 2004, 97: 1559-1566

8 Tuder R M, Zhen L, Cho C Y, et al. Oxidative stress and apoptosis interact and cause emphysema due to vascular endothelial growth factor receptor blockade. Am J Respir Cell Mol Biol, 2003, 29: 8897

9 Rennard S I, Togo S, Holz O. Cigarette smoke inhibits alveolar repair a mechanism for the development of emphysema. Proc Am Thorac Soc, 2006, 3: 703-708

10 Zhang J, Hagopian-Donaldson S, Serbedzija G. Neural tube, skeletal and body wall defects in mice lacking transcription factor AP-2. Nature, 1996, 381: 238-241

11 Douglas D B, Akiyama Y, Carraway H, et al. Hypermethylation of a small CpGuanine-rich region correlates with loss of activator protein-2alpha expression during progression of breast cancer. Cancer Res, 2004, 64: 1611-1620

12 Müller F U, Loser K, Kleideiter U, et al. Transcription factor AP-2 $\alpha$ lpha triggers apoptosis in cardiac myocytes. Cell Death Differ, 2004, 5: 485-493

13 Ruiz M, Pettaway C, Song R, et al. Activator protein 2alpha inhibits tumorigenicity and represses vascular endothelial growth factor transcription in prostate cancer cells. Cancer Res, 2004, 64: 631-638

14 Haupt S, Berger M, Goldberg Z, et al. Apoptosis: The p53 network. J Cell Sci, 2003, 116: 4077-4085

15 Ropponen K M, Kellokoski J K, Lipponen P K, et al. P22/WAF1 expression in human colorectal carcinoma: Association with p53, transcription factor AP-2 and prognosis. Br J Cancer, 1999, 81: 133-140

16 Wajapeyee N, Britto R, Ravishankar H M, et al. Apoptosis induction by activator protein 2alpha involves transcriptional repression of Bcl-2. J Biol Chem, 2006, 281: 16207-16219

17 Xu Y, Porntadavity S, St Clair D K. Transcriptional regulation of the human manganese superoxide dismutase gene: The role of specificity protein 1 (Sp1) and activating protein-2 (AP-2). Biochem J, 2002, 362: 401-412

18 Kasagi S, Seyama K, Mori H, et al. Tomato juice prevents senescence-accelerated mouse P1 strain from developing emphysema induced by chronic exposure to tobacco smoke. Am J Physiol Lung Cell Mol Physiol, 2006, 290: L396-L404

19 Xu L, Cai B Q, Zhu Y J. Pathogenesis of cigarette smoke-induced chronic obstructive pulmonary disease and therapeutic effects of glucocorticoids and $N$-acetylcysteine in rats (in Chinese). Chin Med J, 2004, 117: 1611-1619

20 Saetta M, Shiner R J, Angus G E, et al. Destructive index: A measurement of lung parenchymal destruction in smokers. Am Rev Respir Dis, 1985, 131: 764-769

21 Chen T, Wu Y M. Study on the roles of interstitial collagenase and tissue-inhibitors metalloproteinase-1 in the rat model of chronic obstructive pulmonary disease (in Chinese). Chinese J Respirat Crit Care Med, 2004, 3: 387-391

22 Chen P, Cai Y, Yang Z G, et al. Involvement of PKC, p38MAPK and
AP-2 in IL-1 $\beta$-induced expression of cyclooxygenase-2 in human pulmonary epithelial cells. Respirology, 2006, 11: 18-23

23 Hishikawa K, Oemar B S, Tanner F C, et al. Connective tissue growth factor induces apoptosis in human breast cancer cell line MCF-7. J Biol Chem, 1999, 274: 37461-37466

24 Blagosklonny M V, El-Deiry W S. In vitro evaluation of a p53expressing adenovirus as an anti-cancer drug. Int J Cancer, 1996, 67: 386-392

25 Schreiber E, Matthias P, Müller M M, et al. Rapid detection of octamer binding proteins with "mini-extracts" prepared from a small number of cells. Nucleic Acids Res, 1989, 17: 6419-6920

26 Anttila M A, Kellokoski J K, Moisio K I, et al. Expression of transcription factor AP-2a predicts survival in epithelial ovarian cancer. Br J Cancer, 2000, 82: 1974-1983

27 Ropponen K M, Kellokoski J K, Pirinen R T, et al. Expression of transcription factor AP-2 in colorectal adenomas and adenocarcinomas, comparison of immunohistochemistry and in situ hybridisation. J Clin Pathol, 2001, 54: 533-538

28 Heimberger A B, McGary E C, Suki D, et al. Loss of the AP- $2 \alpha$ transcription factor is associated with the grade of human gliomas. Clin Cancer Res, 2005, 11: 267-272

29 Ruiz M, Pettaway C, Song R, et al. Activator protein $2 \alpha$ inhibits tumorigenicity and represses vascular endothelial growth factor transcription in prostate cancer cells. Cancer Res, 2004, 64: 631-638

30 Gershenwald J E, Sumner W, Calderone T, et al. Dominant-negative transcription factor AP-2 augments SB-2 melanoma tumor growth in vivo. Oncogene, 2001, 20: 3363-3375

31 Turner B C, Zhang J, Gumbs A A, et al. Expression of AP-2 transcription factors in human breast cancer correlates with the regulation of multiple growth factor signalling pathways. Cancer Res, 1998, 58: 5466-5472

32 Taraseviciene-Stewart L, Douglas I S, Nana-Sinkam P S. Is alveolar destruction and emphysema in chronic obstructive pulmonary disease an immune disease? Proc Am Thorac Soc, 2006, 3: 687-690

33 Wang S B, Cheng Y N, Cui S X, et al. Des-gamma-carboxy prothrombin stimulates human vascular endothelial cell growth and migration. Clin Exp Metastasis, 2009, 26: 469-477

34 Ameshima S, Golpon H, Cool C D, et al. Peroxisome proliferator-activated receptor gamma (PPAR gamma) expression is decreased in pulmonary hypertension and affects endothelial cell growth. Circ Res, 2003, 92: 1162-1169

35 Liu X, Conner H, Kobayashi T, et al. Cigarette smoke extract induces DNA damage but not apoptosis in human bronchial epithelial cells. Am J Respir Cell Mol Biol, 2005, 33: 121-129

36 Slebos D J, Ryter S W, van der Toorn M, et al. Mitochondrial localization and function of heme oxygenase-1 in cigarette smoke-induced cell death. Am J Respir Cell Mol Biol, 2007, 36: 409-417

37 van der Toorn M, Slebos D J, de Bruin H G, et al. Cigarette smoke-induced blockade of the mitochondrial respiratory chain switches lung epithelial cell apoptosis into necrosis. Am J Physiol Lung Cell Mol Physiol, 2007, 292: L1211-L1218

$38 \mathrm{Xu}$ Y, Krishnan A, Wan X S, et al. Mutations in the promoter reveal a cause for the reduced expression of the human manganese superoxide dismutase gene in cancer cells. Oncogene, 1999, 18: 93-102

39 Schwartz B, Melnikova V O, Tellez C, et al. Loss of AP-2alpha results in deregulation of E-cadherin and MMP-9 and an increase in tumorigenicity of colon cancer cells in vivo. Oncogene, 2007, 26: 4049-4058

40 Yu L, Hitchler M J, Sun W, et al. AP-2 $\alpha$ inhibits c-MYC induced oxidative stress and apoptosis in $\mathrm{HaCaT}$ human keratinocytes. J Oncol, 2009, 2009: 780874

41 Rosenwasser L J. Biologic activities of IL-1 and its role in human disease. J Allergy Clin Immunol, 1998, 102: 344-350

Open Access This article is distributed under the terms of the Creative Commons Attribution License which permits any use, distribution, and reproduction in any medium, provided the original author(s) and source are credited. 